\title{
Genome-wide subcellular localization of putative outer membrane and extracellular proteins in Leptospira interrogansserovar Lai genome using bioinformatics approaches Wasna Viratyosin*1, Supawadee Ingsriswang ${ }^{1}$, Eakasit Pacharawongsakda ${ }^{1}$ and Prasit Palittapongarnpim ${ }^{1,2}$
}

\author{
Address: ${ }^{1}$ BIOTEC Central Research Unit, National Center for Genetic Engineering and Biotechnology, Pathumthani, 12120, Thailand and \\ ${ }^{2}$ Department of Microbiology, Faculty of Science, Mahidol University, Bangkok, 10400, Thailand \\ Email: Wasna Viratyosin* - wasna@biotec.or.th; Supawadee Ingsriswang - supawadee@biotec.or.th; \\ Eakasit Pacharawongsakda - eakasit.pac@biotec.or.th; Prasit Palittapongarnpim - Prasit@biotec.or.th \\ * Corresponding author
}

Published: 16 December 2008

BMC Genomics 2008, 9:602 doi:10.1 186/147|-2164-9-602

This article is available from: http://www.biomedcentral.com/I47I-2/64/9/602

(c) 2008 Viratyosin et al; licensee BioMed Central Ltd.

This is an Open Access article distributed under the terms of the Creative Commons Attribution License (http://creativecommons.org/licenses/by/2.0), which permits unrestricted use, distribution, and reproduction in any medium, provided the original work is properly cited.

\section{Correction}

After the publication of this work [1], we discovered a typographic error in Table 6 (56 Putative extracellular proteins (EX) derived from the 1 out of 3 predictions with significant DBSubloc or/and GTD prediction). For the entry of LA3370/LIC10793 (a conserved hypothetical protein/ surface antigen) [1], the homologous structure predicted by GTD should read, "110q", a structural surface layer of protein binding containing tandem beta propeller. In the final print version, it appeared as 1 loq (letter o replacing zero). This distinction is important as 1 loq is the PDB structural code for a different protein, Orotidine 5'-phosphate decarboxylase, which is localized as cytoplasmic and not extracellular or secreted.

\section{References}

I. Viratyosin W, Ingsriswang S, Pacharawongsakda E, Palittapongarnpim P: Genome-wide subcellular localization of putative outer membrane and extracellular proteins in Leptospira interrogans serovar Lai gen. BMC Genomics 2008, 9:181.
Received: 3 November 2008

Accepted: 16 December 2008 